\title{
Faktor Risiko Pneumonia pada Anak dengan Penyakit Jantung Bawaan
}

\author{
Tia Harelina, ${ }^{*}$ Retno Asih Setyoningrum, ${ }^{* *}$ Yan Efrata Sembiring ${ }^{* *}$ \\ "Mahasiswa Fakultas Kedokteran Universitas Airlangga \\ ${ }^{* *}$ Departemen Kesehatan Anak Fakultas Kedokteran Universitas Airlangga/RSUD Dr. Soetomo, Surabaya \\ ${ }^{* * *}$ Departemen Bedah Toraks dan Kardiovaskular Fakultas Kedokteran Universitas Airlangga/RSUD Dr. Soetomo, Surabaya
}

Latar belakang. Penyakit jantung bawaan (PJB) merupakan faktor risiko utama yang memperparah infeksi saluran pernapasan bawah akut. Infeksi saluran pernapasan bawah akut yang paling umum adalah pneumonia. Beberapa faktor predisposisi untuk pneumonia telah diidentifikasi, seperti pada malnutrisi berat.

Tujuan. Untuk mengetahui faktor risiko kejadian pneumonia anak dengan penyakit jantung bawaan di RSUD Dr.Soetomo Surabaya. Metode. Jenis penelitian ini adalah analitik observasional dengan desain kasus kontrol berdasarkan data rekam medik pasien yang dirawat di Ruang Rawat Inap SMF Ilmu Kesehatan Anak RSUD Dr. Soetomo Surabaya selama periode Januari 2016 sampai dengan Desember 2016. Analisis data dilakukan dengan uji chi-square dan regresi logistik. Kriteria inklusi untuk kelompok kasus adalah pasien PJB dengan pneumonia, sedangkan kelompok kontrol pasien PJB tanpa pneumonia dengan umur 1 bulan sampai 60 bulan. Kriteria eksklusi adalah rekam medik yang tidak lengkap.

Hasil. Diperoleh subjek sebesar 66 pasien, dengan perbandingan kasus-kontrol 1:1. Hasil analisis multivariat ditemukan adanya hubungan yang signifikan antara anemia dengan kejadian pneumonia pada anak dengan PJB ( $\mathrm{p}=0,002)$ dan terdapat hubungan yang signifikan antara neuromuscular disease dengan kejadian pneumonia pada anak dengan PJB ( $\mathrm{p}=0,015)$.

Kesimpulan. Adanya hubungan antara anemia dan neuromuscular disease dengan pneumonia pada anak dengan penyakit jantung bawaaan. Sari Pediatri 2020;21(5):276-81

Kata kunci: pneumonia, penyakit jantung bawaan, anak

\section{Risk Factors of Pneumonia in Children with Congenital Heart Disease}

\author{
Tia Harelina, ${ }^{*}$ Retno Asih Setyoningrum, ${ }^{* *}$ Yan Efrata Sembiring***
}

Background. Congenital heart disease is a major risk factor that worsens acute lower respiratory tract infections. The most common acute lower respiratory tract infection is pneumonia. Several predisposing factors for pneumonia have been identified, such as in severe malnutrition.

Objective. To find out the risk factors for pneumonia in children with congenital heart disease in Dr. Soetomo Hospital Surabaya. Methods. This type of research is observational analytic with case-control design based on medical record data of patients treated during the period from January 2016 to December 2016. Data analysis was performed by Chi-Square test and Logistic Regression. The inclusion criteria of this study for the case group were congenital heart disease patients with pneumonia while the control group was congenital heart disease patients without pneumonia with age 1 months to 60 months. Exclusion criteria are incomplete medical records.

Result. A total of 66 patients were found to be subjected, with case-control ratio of 1:1. The results of multivariate analysis found a significant association between anemia and the incidence of pneumonia in children with congenital heart disease ( $\mathrm{p}=0.002)$ and there was a significant relationship between neuromuscular disease and the incidence of pneumonia in children with congenital heart disease $(\mathrm{p}=0.015)$.

Conclusion. There is a relationship between anemia and neuromuscular disease with pneumonia in children with congenital heart disease. Sari Pediatri 2020;21(5):276-81

Keywords: pneumonia, congenital heart disease, children

Alamat korespondensi: Retno Asih Setyoningrum. Departemen Ilmu Kesehatan Anak Fakultas Kedokteran Universitas Airlangga, Jl. Mayjen Prof. Dr. Moestopo Np.6-8, Surabaya, Jawa Timur 60286. Email: retnosoedijo@yahoo.co.id 
$\mathrm{P}$ enyakit jantung bawaan (PJB) merupakan faktor risiko utama yang memperparah infeksi saluran pernapasan bawah akut. ${ }^{1}$ Infeksi saluran pernapasan bawah akut yang paling umum adalah pneumonia. ${ }^{2}$ Pneumonia adalah penyebab kematian terbesar pada anak di seluruh dunia dan merupakan infeksi saluran pernapasan akut yang memengaruhi paru. Ketika seorang individu menderita pneumonia, alveoli terisi dengan nanah dan cairan, membuat kesulitan bernapas, dan asupan oksigen berkurang. ${ }^{3}$ Kondisi yang mendasari kematian pneumonia pada anak seperti penyakit paru kronis prematuritas, PJB, dan imunokompromais. ${ }^{2}$

Berdasarkan penelitian Sadoh dan Osarogiagbon ${ }^{4}$ di Nigeria, terdapat 121 anak yang menderita pneumonia, dengan $50,4 \%$ adalah laki-laki. Dari 121 anak yang menderita PJB, 14 (11,57\%) adalah PJB yang paling sering terjadi, yaitu ventricular septal defect (VSD) sekitar 50\% dari 14 anak, yang menyebabkan shunting kiri ke kanan darah dan meningkatkan aliran darah di paru. Ventricular septal defect yang tidak tertutup dan patent ductus arteriosus (PDA) besar diketahui dengan gejala yang muncul lebih awal dan memiliki kecenderungan yang lebih besar untuk menderita pneumonia pada anak. Pasien pneumonia dengan PJB cenderung mengalami gagal jantung dan lebih lama di rumah sakit dibandingkan dengan anak tanpa PJB. Pasien PJB dengan peningkatan aliran darah ke paru yang signifikan lebih mudah terjadi pneumonia dan gagal jantung kongestif.

Penelitian oleh Owayad $\mathrm{dkk}^{5}$ tentang beberapa faktor predisposisi untuk pneumonia telah diidentifikasi, yang utama dan umum termasuk gangguan kekebalan seperti yang terlihat pada malnutrisi berat, defisiensi imun bawaan terutama human immune-deficiency virus (HIV).

Berdasarkan uraian di atas, penting untuk dilakukan evaluasi kontribusi PJB terhadap pneumonia sehingga dapat dilakukan pencegahan dan penanganan untuk menurunkan angka kejadian pneumonia. Salah satu yang dapat dilakukan adalah dengan mengetahui berbagai faktor risiko yang berpengaruh terhadap terjadinya pneumonia. Oleh karena itu, penelitian ini bertujuan untuk mengidentifikasi faktor risiko kejadian pneumonia pada anak dengan penyakit jantung bawaan di Rumah Sakit Umum Daerah Dr. Soetomo Surabaya.

\section{Metode}

Jenis Penelitian ini adalah analitik observasional dengan desain kasus kontrol. Pengambilan sampel dilakukan dari rekam medis pasien di Ruang Rawat Inap Staf Medis Fungsional (SMF) Ilmu Kesehatan Anak RSUD Dr. Soetomo Surabaya periode Januari 2016 sampai Desember 2016. Subyek adalah semua anak dengan PJB yang memenuhi kriteria inklusi dan eksklusi. Kriteria inklusi adalah data rekam medis pasien dengan diagnosis PJB dengan pneumonia untuk kelompok kasus dan PJB dan pasien tanpa pneumonia untuk kelompok kontrol dan pasien berumur 1 bulan sampai 60 bulan. Kriteria eksklusi adalah ditemukannya pasien dengan rekam medis yang tidak lengkap.

Adapun faktor risiko yang diteliti, yakni berupa anemia, hipoksemia, status gizi, gagal jantung kongestif dan neuromuscular disorders. Dilakukan pengambilan data dari rekam medis yang meliputi jenis kelamin, umur, berat badan atau tinggi badan, kadar hemoglobin, saturasi oksigen, penyakit gagal jantung dan gangguan neuromuskular.

Batasan operasional yang digunakan adalah sebagai berikut, diagnosis untuk pneumonia dengan PJB melalui anamnesis, pemeriksaan fisik dan pemeriksaan penunjang. Pada pasien PJB sianotik untuk mendiagnosis hipoksemia dibedakan menjadi dua, yaitu menggunakan hyperoxic-test dan hasil analisis gas darah, untuk hyperoxic-test $(\mathrm{SaO} 2<90 \%)$ dan hasil analisis gas darah $(\mathrm{SaO} 2<85 \%, \mathrm{PaO} 2$ arterial $<60 \mathrm{mmHg}, \mathrm{SpO} 2<95 \%$ ), sedangkan pada pasien PJB asianotik hanya berdasarkan analisis gas darah $(\mathrm{SaO} 2 \geq 90 \%)$. Dapat dikatakan anemia jika pada pasien PJB asianotik memiliki kadar hemoglobin $<12 \mathrm{~g} /$ dL dan pada pasien PJB sianotik $<15 \mathrm{~g} / \mathrm{dL}$.

Nilai status gizi anak didasarkan pada berat badan menurut panjang badan atau tinggi badan sesuai dengan kurva pertumbuhan $\mathrm{WHO}$ (untuk anak berusia $<5$ tahun). Obesitas (> $2 \mathrm{SD})$, overweight (> $1 \mathrm{SD}$ hingga $2 \mathrm{SD})$, normal (-2SD hingga 1 SD), kurus (-3 SD hingga $<-2$ SD) dan sangat kurus (<-3 SD). Gagal jantung kongestif dan neuromuscular disorder di diagnosis melalui anamnesis, pemeriksaan fisik, dan pemeriksaan penunjang.

Pengolahan data menggunakan chi square untuk analisis bivariat, sedangkan untuk analisis multivariat menggunakan uji regresi logistik. Tingkat kemaknaan dalam penelitian ini dinyatakan bila $\mathrm{p}<0,05$. Penelitian ini sudah mendapat persetujuan oleh komite etik penelitian dan dinyatakan laik etik. 
Tia Harelina dkk: Faktor risiko pneumonia pada anak dengan penyakit jantung bawaan

\section{Hasil}

Selama kurun waktu penelitian didapatkan 33 pasien dari kelompok kasus dan 33 pasien dari kelompok kontrol yang memenuhi kriteria inklusi. Semua subyek berada dalam rentang umur 1- 60 bulan. Distribusi subyek penelitian berdasarkan karakteristik umum, secara menyeluruh tertera pada Tabel 1. Berdasarkan data yang sudah diambil, mayoritas yang menderita PJB dengan pneumonia adalah PJB asianotik, seperti ASD, VSD dan PDA.

Hubungan asosiasi analisis bivariat antara pajanan variabel bebas pada kelompok kasus dengan kelompok kontrol dengan uji chi square untuk menganalisis hubungan faktor risiko anemia, hipoksemia, status gizi, gagal jantung kongestif dan neuromuscular disorders terhadap kejadian pneumonia dengan PJB. Hasil analisis bivariat tertera pada Tabel 2 .

Berdasarkan hasil analisis bivariat tersebut terdapat dua buah variabel yang menunjukkan hubungan signifikan bermakna, yakni anemia ( $\mathrm{p}=0,001$; $\mathrm{OR}=8,700 ; \mathrm{IK} 95 \%=2,493-30,364)$ dan neuromuscular disorders $(\mathrm{p}=0,001 ; \mathrm{OR}=16,000 ; \mathrm{IK} 95 \%=1,925$ 133,014). Di sisi lain, variabel lainnya menunjukkan hasil tidak signifikan dengan nilai $\mathrm{p} \geq 0,05$, seperti hipoksemia $(\mathrm{p}=0,319)$, status gizi $(\mathrm{p}=0,614)$, dan gagal jantung kongestif $(\mathrm{p}=0,306)$.

Analisis multivariat dilakukan dengan regresi logistik, variabel bebas dengan nilai $\mathrm{p}<0,025$ akan dimasukkan dalam model multivariat sebagai variabel kandidat. Terdapat dua variabel yang masuk ke dalam analisis, yaitu variabel anemia dan neuromuscular disorders. Hasil analisis multivariat tertera pada Tabel 3.

Hasil analisis multivariat menunjukkan bahwa anemia dan neuromuscular disorders signifikan terhadap kejadian pneumonia dengan penyakit jantung bawaan dengan nilai $\mathrm{p}=0,002(\mathrm{OR}=9,026$; IK95\% $=2,235$ $36,460)$ untuk anemia dan $\mathrm{p}=0,0015(\mathrm{OR}=16,841$; IK95\% $=1,712-165,628)$ untuk neuromuscular disorders.

\section{Pembahasan}

Faktor risiko pneumonia pada anak dengan PJB yang diteliti pada adalah faktor anemia, hipoksemia, status gizi, gagal ajntung kongestif dan neuromuscular disorders. Hasil penelitian menunjukkan bahwa hanya faktor anemia dan neuromuscular disorders
Tabel 1. Karakteristik umum subyek penelitian

\begin{tabular}{|c|c|c|}
\hline & $\begin{array}{c}\text { PJB dengan } \\
\text { pneumonia } \\
\mathrm{n}(\%)\end{array}$ & $\begin{array}{l}\text { PJB tanpa } \\
\text { pneumonia } \\
\mathrm{n}(\%)\end{array}$ \\
\hline \multicolumn{3}{|l|}{ Umur } \\
\hline 1 bulan -12 bulan & $25(75,8)$ & $12(36,4)$ \\
\hline 13 bulan -60 bulan & $8(24,2)$ & $21(63,6)$ \\
\hline \multicolumn{3}{|l|}{ Jenis kelamin } \\
\hline Laki-laki & $20(60,6)$ & $15(45,5)$ \\
\hline Perempuan & $13(39,4)$ & $18(54,5)$ \\
\hline \multicolumn{3}{|l|}{ Anemia } \\
\hline Ya & $29(87,9)$ & $15(45,5)$ \\
\hline Tidak & $4(12,1)$ & $18(54,5)$ \\
\hline \multicolumn{3}{|l|}{ Hipoksemia } \\
\hline Ya & $14(42,4)$ & $20(60,6)$ \\
\hline Tidak & $19(57,6)$ & $13(39,4)$ \\
\hline \multicolumn{3}{|l|}{ Status gizi } \\
\hline Malnutrisi & $21(63,6)$ & $19(57,6)$ \\
\hline Normal & $12(36,4)$ & $14(42,4)$ \\
\hline \multicolumn{3}{|l|}{ Gagal jantung kongestif } \\
\hline Ya & $14(42,4)$ & $10(30,3)$ \\
\hline Tidak & $19(57,6)$ & $23(69,7)$ \\
\hline \multicolumn{3}{|l|}{ Neuromuscular disorders } \\
\hline Ya & $11(33,3)$ & $1(3,0)$ \\
\hline Tidak & $22(66,7)$ & $32(97,0)$ \\
\hline
\end{tabular}

yang berhubungan secara bermakna dengan kejadian pneumonia pada anak dengan PJB.

Hubungan anemia dengan kejadian pneumonia pada anak dengan PJB dibuktikan berhubungan secara bermakna. Hasil menunjukkan bahwa $28(84,8 \%)$ dari 33 anak yang menderita PJB non sianotik dengan pneumonia mengalami anemia, sedangkan di antara 19 pasien PJB non sianotik tanpa pneumonia terdapat $12(63,1 \%)$ yang menderita anemia. Selain itu, anak yang menderita PJB sianotik dengan pneumonia tidak ada yang mengalami anemia dan anak yang menderita PJB sianotik tanpa pneumonia di dapatkan $3(21,4 \%)$ yang mengalami anemia dari 14 anak.

Anemia sering dikaitkan dengan pneumonia dan PJB, seperti penelitian Kisworini $\mathrm{dkk}^{6}$ dan Rashad $\mathrm{dkk}^{7}$ yang melaporkan adanya hubungan bermakna antara anemia dengan kejadian pneumonia pada anak. Namun, kedua penelitian tersebut memiliki perbedaan dengan penelitian ini dalam hal besar 
Tabel 2. Hasil analisis bivariat

\begin{tabular}{llllll}
\hline Variabel bebas & $\begin{array}{l}\text { Kasus } \\
(\mathrm{n})\end{array}$ & $\begin{array}{l}\text { Kontrol } \\
(\mathrm{n})\end{array}$ & Nilai-p & OR & IK 95\% \\
\hline $\begin{array}{l}\text { Anemia } \\
\text { Ya }\end{array}$ & 29 & 15 & 0,000 & 8,700 & $2,493-30,364$ \\
$\quad$ Tidak & 4 & 18 & & & \\
$\begin{array}{l}\text { Hipoksemia } \\
\quad \text { Ya }\end{array}$ & 14 & 20 & 0,319 & 0,479 & $0,179-1,279$ \\
$\quad$ Tidak & 19 & 13 & & & \\
$\begin{array}{l}\text { Status gizi } \\
\text { Malnutrisi }\end{array}$ & 21 & 19 & 0,614 & 1,289 & $0,479-3,469$ \\
$\quad$ Normal & 12 & 14 & & & \\
$\begin{array}{l}\text { Gagal jantung } \\
\text { kongestif }\end{array}$ & & & & & \\
$\quad$ Ya & 14 & 10 & 0,306 & 1,695 & $0,615-4,671$ \\
$\quad$ Tidak & 19 & 23 & & & \\
$\begin{array}{l}\text { Neuromuscular } \\
\text { disorders }\end{array}$ & & & & & \\
$\quad$ Ya & 11 & 1 & 0,001 & 16,000 & $1,925-133,014$ \\
$\quad$ Tidak & 22 & 32 & & & \\
\hline
\end{tabular}

Tabel 3. Analisis multivariat variabel bebas terhadap pneumonia dengan PJB (final model)

\begin{tabular}{|c|c|c|c|c|c|}
\hline \multirow{3}{*}{ Variabel bebas } & \multirow{3}{*}{$\begin{array}{l}\text { Koefisien } \\
\text { (B) }\end{array}$} & \multirow{3}{*}{$\mathrm{p}$} & \multirow{3}{*}{ OR } & \multicolumn{2}{|c|}{ IK 95\% } \\
\hline & & & & Batas & Batas \\
\hline & & & & bawah & atas \\
\hline Anemia & 2,200 & 0,002 & 9,026 & 2,235 & 36,460 \\
\hline Neuromuscular disorders & 2,824 & 0,015 & 16,841 & 1,712 & 165,628 \\
\hline Constant & $-3,111$ & 0,007 & 0,045 & & \\
\hline
\end{tabular}

sampel, mengeksklusi pasien dengan PJB, dan juga memiliki kesamaan dalam jenis penelitian. Selain itu, di dukung oleh El-Sakka dkk ${ }^{8}$ bahwa kadar hemoglobin yang rendah merupakan faktor risiko untuk infeksi saluran pernapasan akut bawah dengan $62,5 \%$ pasien pneumonia pada anak. Ramakrishnan dan Harish ${ }^{9}$ menjelaskan bahwa kadar hemoglobin rendah menjadi faktor risiko serius karena mengurangi nilai kuantitatif atau kualitatif hemoglobin yang dapat memengaruhi fungsi normal.

Penelitian terbaru di Nepal melaporkan bahwa suplementasi besi bersama asam folat dapat mengurangi insiden infeksi saluran pernapasan akut bawah secara bermakna, kemungkinan besar berkaitan dengan perbaikan fungsi imunitas. ${ }^{10}$ Sementara, menurut penelitian Hariyanto ${ }^{11}$ yang juga melaporkan adanya hubungan bermakna anemia dengan kejadian PJBpada anak. Namun demikian, terdapat perbedaan jenis penelitian dan besaran sampel dengan penelitian ini. Selain memiliki perbedaan juga memiliki kesamaan dengan penelitian ini yaitu PJB non sianotik paling banyak ditemui yang mengalami anemia.

Pada anak dengan PJB pirau kanan ke kiri menyebabkan penurunan saturasi oksigen arteri kronik, terjadi peningkatan jumlah eritrosit dan berakibat viskositas darah tinggi. Selain itu, pada pasien dengan PJB sianotik yang menderita anemia, terutama karena anemia defisiensi besi hipokromik, sel darah merah kurang permeabel dan konsentrasi hemoglobin dalam kisaran normal. Hal ini mungkin menyiratkan bahwa pasien relatif mengalami anemia. Kondisi ini mungkin memiliki efek negatif pada mortalitas dan morbiditas. ${ }^{12}$

Hasil penelitian menunjukkan tidak adanya hubungan antara hipoksemia dengan kejadian pneumonia Hasil ini berbeda dengan penelitian Basnet $\mathrm{dkk}^{13}$ dan Salah $\mathrm{dkk}^{14}$ yang melaporkan adanya hubungan bermakna 
antara hipoksemia dengan kejadian pneumonia pada anak. Graaff $\mathrm{dkk}^{15}$ melaporkan bahwa insiden hipoksemia meningkat pada usia muda dan insiden tertinggi terdapat pada neonatus. Menurut teori Bancalari dkk, ${ }^{16}$ PJB sianotik dengan pirau kanan ke kiri sering ditemukan hipoksemia karena derajat stenosis pulmonalnya bertambah setiap waktu sehingga risiko serangan hipersianotik meningkat. Hasil penelitian ini berbeda dengan penelitian yang lain dikarenakan jumlah sampel kasus dan kontrol yang telah diambil mayoritas dengan PJB asianotik. Sementara berdasarkan penelitian penelitian yang sudah ada mayoritas pada pasien dengan PJB sianotik.

Penelitian ini tidak menemukan hubungan antara status gizi dengan kejadian pneumonia. Hasil ini berbeda dengan penelitian Wiliar dan Wantania ${ }^{17}$ yang melaporkan adanya hubungan bermakna antara status gizi dengan kejadian infeksi saluran pernapasan akut. Penelitian oleh Gabriela $\mathrm{dkk}^{18}$ juga membuktikan bahwa anak dengan infeksi saluran pernapasan bawah akut mengalami malnutrisi yang didominasi jumlah gizi kurang yang lebih banyak dibandingkan gizi buruk. Adriani $\mathrm{dkk}^{19}$ melaporkan bahwa malnutrisi merupakan salah satu faktor risiko morbiditas dan mortalitas pneumonia pada anak usia di bawah 5 tahun. Penelitian ini menggunakan perhitungan berdasarkan kurva pertumbuhan WHO. Hasil yang berbeda dapat disimpulkan karena penelitian sebelumnya menggunakan perhitungan status gizi yang berbeda dengan penelitian ini. Terdapat berbagai cara perhitungan status gizi seperti menggunakan center for disease control and prevention (CDC), Kementrian Kesehatan, dan lain sebagainya.

Selain itu, penelitian ini juga tidak menemukan hubungan antara gagal jantung kongestif dengan kejadian pneumonia. Berdasarkan penelitian Sadoh dan Osarogiagbon ${ }^{4}$ melaporkan hasil bahwa gagal jantung kongestif memiliki risiko lebih tinggi pada pneumonia dengan PJB dibandingkan yang tidak memiliki pneumonia, tetapi tidak menunjukkan hubungan yang bermakna. Hal tersebut dimungkinkan karena jumlah sampel yang terlalu kecil. Sesuai dengan teori Owayad $\mathrm{dkk}^{5}$ bahwa pneumonia dan gagal jantung kongestif sebagai tanda adanya PJB.

Uji statistik menunjukkan adanya hubungan antara neuromuscular disorders dengan kejadian pneumonia. Dari penelitian ini dapat diketahui bahwa neuromuscular disorders yang paling banyak ditemukan adalah sindrom Down. Berdasarkan Penelitian Ain $\mathrm{dkk}^{20}$ juga dilaporkan bahwa neuromuscular disorders yang paling banyak ditemukan adalah penyakit sindrom Down.

Menurut Penelitian Monita dkk, ${ }^{21}$ sindrom Down juga menjadi penyakit penyerta pada pasien anak dengan pneumonia. Hasil tersebut di dukung oleh teori Perez dan Guerra ${ }^{22}$ yang melaporkan bahwa pasien dengan sindrom Down cenderung memiliki defisiensi imun sehingga sering mengalami pneumonia. Selain itu, sering terjadinya infeksi saluran pernapasan pada anak dengan sindrom Down dikarenakan fungsi dan struktur sistem pernapasan yang abnormal, seperti anteroposterior nasofaring yang sempit mengakibatkan terhambatnya drainase yang adekuat, pembentukan sinus dan mukosa hidung yang tidak baik, serta penurunan aktivitas silia untuk menjaga mukosa hidung agar tetap bersih.

\section{Kesimpulan}

Anemia dan neuromuscular disorders menjadi faktor risiko pneumonia pada anak dengan PJB.

\section{Saran}

Tenaga kesehatan sebaiknya memperhatikan pasien yang mengalami anemia dan memiliki neuromuscular disorders pada pneumonia dengan PJB yang datang untuk mengantisipasi kedepannya. Penelitian selanjutnya diharapkan dapat meneliti mengenai fakto risiko lain yang belum diteliti seperti hipertensi pulmonal, faktor sosial dan sebagainya.

\section{Daftar pustaka}

1. Kim NK, Choi JY. Respiratory Syncytial Virus Prevention in Children with Congenital Heart Disease: Who and How?. Korean J Pediatrics 2011;54:197-200.

2. Bennett NJ. Pediatric pneumonia. Dikutip 3 Mei 2018. Didapat dari: https://emedicine.medscape.com/article/967822overview

3. World Health Organization. Pneumonia. Dikutip 5 April 2018. Didapat dari: http://www.who.int/en/news-room/factsheets/detail/pneumonia.

4. Sadoh WE., Osarogiagbon WO. Underlying congenital heart disease in Nigerian children with pneumonia. Afr Health Sci 
2013;13:607-12.

5. Owayad AF, Campbell DM, Wang EE. Underlying causes of recurrent pneumonia in children. Arch Pediatric Adolesc Med 2000;154:190-4.

6. Kisworini P, Amalia S, Sutaryo S. Mortality predictors of pneumonia in children. Paediatrica Indones 2010;50:149-53.

7. Rashad MM, Fayed SM, El-hag AMK. Iron-deficiency anemia as a risk factor for pneumonia in children. Ben Med J 2015;2:96-100.

8. El Sakka AS, Safaa SI, Hanaa AA, Samah AM. Vitamin D deficiency and low hemoglobin level as risk factors for severity of acute lower respiratory tract infections in Egyptian children: A case-control study. Egyptian Pediatric Association Gazette 2014;62:1-7.

9. Ramakrishnan K, Harish PS. Hemoglobin level as a risk factor for lower respiratory tract infections. Indian J Pediatrics 2006;73:881-3.

10. Wirawan IKA, Ariawati K, Subanada ID. Prevalence and hematology profile of anemia in patients with acute lower respiratory infection. Medicina 2012;:89-94.

11. Hariyanto, D. Profil penyakit jantung bawaan di instalasi rawat inap anak RSUP Dr. M. Djamil Padang Januari 2008-Februari 2011. Sari Pediatri 2012;14:152-7.

12. Ceku M, Berisha M, Bejiqi R, Retkoceri R. 839 iron deficiency anemia in children with congenital heart disease. Pediatric Res 2010;68(421) doi.org/10.1203/00006450-20101100100839.

13. Basnet S, Adhikari RK, Gurung CK. Hypoxemia in children with pneumonia and its clinical predictors. Indian J Pediatrics 2006;73:777-82.

14. Salah ET, Algasim SH, Mhamoud AS, Husian, NEOSA.
Prevalence of hypoxemia in under-five children with pneumonia in an emergency pediatrics hospital in Sudan. Indian J Crit Care Med 2015;19:203-7.

15. De Graaff JC, Bijker JB, Kappen TH, Van Wolfswinkel L, Zuithoff NP, Kalkman CJ. Incidence of intraoperative hypoxemia in children in relation to age. Anesth Analg 2013;117:169-75.

16. Bancalari E, Jesse MJ, Gelband H, Garcia O. Lung mechanics in congenital heart disease with increased and decreased pulmonary blood flow. J Pediatrics 1977;90:192-95

17. Wiliar R, Wantania JM. Beberapa faktor yang berhubungan dengan episode infeksi saluran pernapasan akut pada anak dengan penyakit jantung bawaan. Sari Pediatri 2006;8:154-8.

18. Gabriela K, Kuswiyanto RB, Dwiyatningrum F. Clinical characteristic and outcome of acute lower respiratory tract infection in children with congenital heart disease. Althea Med J 2015;2:403-8.

19. Adriani N, Nataprawira HM, Alwi EH. Faktor risiko morbiditas dan mortalitas pneumonia berat pada anak usia balita. Majalah Kedokt Indonesia 2010;60:443-7.

20. Ain N, Didik H, Sovina R. Karakteristik penderita penyakit jantung bawaan pada anak di RSUP Dr. M. Djamil Padang periode Januari 2010-Mei 2012. Jurnal Kesehatan Andalas 2015;4:928-35.

21. Monita O, Finny FY, Yuniar L. Profil pasien pneumonia komunitas di bagian anak RSUP DR. M. Djamil Padang Sumatera Barat. Jurnal Kesehatan Andalas 2015;4:218-26.

22. Perrez JAH, Guerra JSH. Community- acquired pneumonia in adults with Down syndrome. Three clinical cases and a review of the literature. Revista Medica Internacional sobre el Sindrome de Down 2010;14:25-30. 